Удосконалення фахової підготовки майбутнього вчителя початкових класів засобом самостійної роботи / I. А. Нагрибельна // Sience Rise. - 2015. - № 3/1 (8). - C. 71-76.

6. Пентилюк М. I. Професійна підготовка студентів-філологів: засвоєння лінгводидактичної термінології / М. І. Пентилюк // Дивослово. - 2005. - №11. - С. 21-24. 7. Солдатенко М. М. Теоретико-методологічні основи розвитку самостійної пізнавальної діяльності майбутнього вчителя: автореф. на здобуття наук. ступеня доктора пед. наук: спец. 13.00.04 «Теорія i методика професійної освіти»/ М. М. Солдатенко. - Київ, 2007. - 47 с. 8. Сисоєва С. О. Нариси з історії розвитку педагогічної думки: [навч. посіб.] / С. О. Сисоєва, І. В. Соколова. Київ : Центр навчальної літератури, 2003. - 308 с. 9. Химинець В. В. Інноваційна освітня діяльність / Василь Васильович Химинець. - Ужгород : ЗІППО, 2007. - 364 с.

УДК 371.13:004(043.3)

Ірина Онищенко

\title{
СУЧАСНІ ВИМОГИ ДО ПРОФЕСІЙНОЇ ПІДГОТОВКИ МАЙБУТНЬОГО ВЧИТЕЛЯ ПОЧАТКОВИХ КЛАСІВ В УМОВАХ ІНФОРМАТИЗАЦІЇ ОСВІТИ
}

Онищенко І. В. Сучасні вимоги до професійної підготовки майбутнього вчителя початкових класів в умовах інформатизації освіти.

У статті з'ясовано особливості впливу інформатизації вищої педагогічної освіти на процес професійної підготовки майбутнього вчителя початкових класів. Визначено основні професійно значущі якості сучасного вчителя початкової школи. Обгрунтовано сучасні вимоги до професійної підготовки майбутнього вчителя початкових класів в умовах інформатизації освіти.

Ключові слова: інформатизація, інформатизація освіти, професійна підготовка, професійне становлення вчителя.

Онищенко И. В. Современные требования к профессиональной подготовке будущего учителя начальных классов в условиях информатизации образования.

В статье раскрыты особенности влияния информатизации высшего педагогического образования на процесс профессиональной подготовки будущего учителя начальных классов. Определены основные профессионально значимые качества современного учителя начальной школы. Обосновано современные требования к профессиональной подготовке будущего учителя начальных классов в условиях информатизации образования.

Ключевые слова: информатизация, информатизация образования, профессиональная подготовка, профессиональное становление учителя.

Onyshchenko I. V. Modern requirements to the professional training of the future primary school teacher in the process of education informatization.

The article deals with peculiarities of the influence of the higher pedagogical education informatization on the process of the professional training of the future primary school teacher. The main professional qualities of the modern primary school teacher have been determined. The current requirements to the professional training of the primary school teacher in the process of education informatization have been grounded.

Key words: informatization, education informational, professional training, the professional growth of the teacher. 
Сучасний розвиток людства характеризується глобальним процесом інформатизації, стрімким переходом на новий етап розвитку- інформаційне суспільство. Питання інформатизації всіх сфер суспільного життя $є$ одним із пріоритетних завдань держави. Формування інформаційного суспільства вимагає модернізації всіх аспектів освітньої системи, передбачає зміну уявлень про роль освіти, висуває нові вимоги до системи навчання, зумовлює потребу переходу від знаннєвої освітньої парадигми індустріального суспільства до компетентнісної парадигми постіндустріального суспільства [9, с. 34-35]. Інформатизація освіти суттєво впливає на зміст, організаційні форми, методи навчання та управління навчально-пізнавальною діяльністю майбутніх фахівців.

В умовах інформатизації освіти традиційні підходи до професійної підготовки майбутніх фахівців вже не розв'язують завдань, які стоять перед сучасною вищою школою. Інформатизація освіти вимагає нових підходів до фахової підготовки вчителів початкової школи. Сучасний рівень освіти повинен забезпечувати підготовку фахівців нового покоління, які будуть конкурентоспроможними на міжнародному ринку праці, готові до своєчасного гнучкого переформатування напряму та змісту професійної діяльності, відбору нових форм, методів та засобів навчання.

Отже, однією 3 основних цілей інформатизації освіти $є$ підготовка вчителів початкових класів, які мають високий рівень інформаційної культури, інформатичної компетентності, комп'ютерної грамотності, готові застосовувати персональний комп'ютер у навчально-виховному процесі початкової школи.

Вимоги до професійної підготовки вчителів початкових класів досліджено й узагальнено у працях К. Авраменка, Т. Байбари, Н. Бібік, О. Біди, М. Богдановича, А. Богуш, В. Бондаря, М. Вашуленка, М. Гриньової, П. Гусака, С. Дорошенка, В. Ільченко, М. Козака, О. Кучерявого, Л. Пєтухової, О. Пєхоти, Н. Побірченко, О. Савченко, Н. Сулаєвої, Г. Тарасенко, Л. Хомич, І. Червінської, І. Шапошнікової та ін.

Упровадження Державного стандарту початкової школи вимагає нових підходів до професійної підготовки кадрів у галузі початкової освіти. Сучасні вимоги до фахової підготовки майбутніх учителів початкових класів розкриті в дослідженнях Н. Бахмат, Л. Веред, А. Коломієць, Н. Кушнір, С. Мартиненко, Н. Олефіренко, Л. Петухової, О. Савченко, С. Сисоєвої, І. Смирнової, О. Снігур, О. Співаковського, О. Суховірського та ін.

Важливим напрямом реформування та модернізації системи вітчизняної освіти є іiі інформатизація. Цей процес суттєво впливає на організацію професійної підготовки майбутніх учителів початкової школи. Психолого-педагогічні аспекти інформатизації освіти досліджувалися в працях В. Бикова, В. Болтянського, Б. Гершунського, А. Сршова, М. Жалдака, Ю. Жука, М. Кадемії, А. Коломієць, Ю. Машбиця, В. Монахова, Н. Морзе, Б. Наумова, Л. Петухової, О. Пєхоти, С. Ракова, Ю. Рамського, С. Семерікова, О. Спіріна, О. Співаковського, Ю. Триуса, О. Трофімова, В. Шакотька, О. Шиман та ін.

Суттєвий інтерес для проведеного дослідження становлять праці, у яких досліджуються проблеми професійної підготовки майбутніх учителів початкових класів в умовах інформаційно-комунікаційного педагогічного середовища. $\mathrm{y}$ дослідженнях Н. Воропай, В. Денисенко, С. Дяченко, А. Коломієць, В. Коткової, Н. Олефіренко, Л. Петухової, О. Співаковського, В. Татаурова, Т. Фадєєвої, Н. Хміль та ін. акцентується увага на необхідності створення інформаційно-комунікаційного педагогічного середовища, яке передбачає повне і ефективне використання потенційних можливостей організаційних форм і методів вищої школи через створення спеціального програмного забезпечення на базі мультимедійних технологій 3 необхідними дидактичними, методичними матеріалами, 
творчими завданнями.

Метою статmі є обгрунтування вимог до професійної підготовки майбутнього вчителя початкових класів в умовах інформатизації освіти.

Головними ознаками сучасної освіти є гуманізація, фундаменталізація, відкритість, безперервність, доступність та інформатизація. Інформатизація освіти є ключовою умовою створення єдиного інформаційного простору, підготовки конкурентоспроможних фахівців, здатних орієнтуватися в навколишньому світі. В ухваленій урядом «Національній стратегії розвитку освіти в Україні на 2012-2021 рр.» визначаються основні напрями, завдання й механізми реалізації державної політики в галузі освіти. У документі наголошено на впровадженні сучасних IКТ, які забезпечать удосконалення навчально-виховного процесу, доступність і ефективність освіти, підготовку молодого покоління до життєдіяльності в інформаційному суспільстві.

Інформатизація професійно-педагогічної підготовки забезпечує ефективність навчально-виховного процесу на основі впровадження нових інформаційних технологій навчання, удосконалює управління підготовкою майбутніх фахівців, сприяє підвищенню інформаційної культури майбутнього вчителя. Слушно зауважують А. Михайлюк, М. Сніжко, Л. Бігун, що інформатизація вищої освіти має не лише не відставати, а й набути випереджального характеру порівнянно зі стрімким розвитком інформаційних технологій та їх використанням у різних сферах людської діяльності, оскільки це є необхідним чинником забезпечення адаптованості випускника навчального закладу до повноцінного функціонування в умовах суспільства знань [5, с. 458].

Професійне становлення майбутнього фахівця, безумовно, відбувається в умовах інформатизації освіти. Основними характеристиками сучасного покоління студентів, як зауважує Н. Кушнір, є технологічна підкованість, залежність від пошукових систем, зацікавленість у мультимедіа, створення інтернет-контенту, ефективність індуктивних методів навчання, багатозадачність у всьому, «візуальне» спілкування, емоційна відкритість, командна робота і співпраця, ведення електронних записів, які безпосередньо пов'язані 3 використанням IКТ і мають враховуватися при організації навчально-виховного процесу. На думку дослідниці, інформаційне суспільство вимагає нових навичок і від сучасного учителя, зокрема, уміння виступати перед дистанційною аудиторією, брати участь в обговореннях за допомогою засобів аудіо- та відеоконференцзв'язку, здійснювати дистанційну навчальну взаємодію, спільно працювати над проектами у мережі тощо [4, с. 150].

Перетворення, що відбуваються у вітчизняній системі освіти відповідно до національних і цивілізаційних пріоритетів, висувають нові вимоги до професійних якостей $і$ рівня підготовки вчителів початкових класів. Учитель $є$ ключовою фігурою освіти, а рівень його професійної підготовки є пріоритетною складовою успішності школи, результативності застосування інноваційних технологій і засобів навчання. На думку Н. Олефіренко, потреби в удосконаленні змісту підготовки майбутнього вчителя початкових класів пов'язані 3 різними аспектами модернізації початкової школи: переходом до реалізації нового Державного стандарту початкової освіти, підтримкою гуманізації освіти, ідей дитиноцентризму у навчанні, запровадження принципів компетентнісного та особистісно зорієнтованого підходів у навчанні молодших школярів, впровадженням інформаційних технологій у навчальний процес початкової школи [7].

Сучасний учитель початкової школи мусить одночасно бути транслятором знань, організатором сумісної навчальної діяльності, дослідником-новатором, експериментатором, розробником освітніх технологій, транслятором соціокультурних цінностей, вихователем, 
психологом, консультантом для батьків. Педагог із такими характеристиками $\epsilon$ конкурентоспроможним та здатним до конкуренції на ринку праці.

Конкурентоздатного вчителя, як зауважує Н. Бахмат, характеризує прагнення досягнення (підкорення) високих цілей - підвищення рівня якості навчання молодого покоління, підготовка учнів до життя та діяльності в умовах інформаційного суспільства тощо. На думку дослідниці, рівень сформованості конкурентоспроможної особистості вчителя початкових класів визначається такими показниками: ціннісно-мотиваційним, когнітивним, діяльнісним, інформаційно-технологічним. Важливим $є$ виокремлення інформаційно-технологічного показника, основу якого складає потенційна підготовленість учителя початкових класів до виконання професійної діяльності в умовах інформаційного суспільства через свідоме розуміння та знання природи, ролі й можливостей інформаційних технологій в особистісному та професійному становленні, самонавчанні та педагогічній діяльності; усвідомлення їх можливості підтримки ефективного розвитку творчості й інноваційності; вміння розробляти, збирати та опрацьовувати навчально-методичні матеріали і використовувати їх у фаховій діяльності відповідно до інноваційного освітнього середовища; здатність до доступу, пошуку та використання сервісів мережі Інтернет, здатність використовувати електронні освітні ресурси тощо [2, с. 262].

Особливістю професійної діяльності вчителя початкових класів є те, що саме він адаптує дітей до освітнього середовища, указує на особливості навчання та самоосвіти в умовах інформаційного середовища школи. Проблема зниження інтересу учнів до вивчення навчальних дисциплін викликана насамперед одноманітним використанням підручників, застосуванням застарілих наочних матеріалів. Отже, важливим завданням, яке стоїть перед учителем початкової школи, є формування в дітей готовності до оволодіння сучасними технологіями отримання інформації і здатності використовувати іiі для подальшої самоосвіти. Для реалізації цієї мети, як підкреслює А. Дедюхіна, постає необхідність застосування в практиці вчителя початкових класів різних стратегій навчання молодших школярів, і передовсім використання інформаційних технологій у навчально-виховному процесі [3, с. 281].

На відміну від учителя-предметника, учитель молодших класів вирізняється значною енциклопедичністю і міжпредметністю знань. Викладання будь-якого предмета в початковій школі має здійснюватися 3 урахуванням вікових особливостей молодших школярів, із залученням специфічних для цього етапу форм і методів навчання. Учитель повинен бути готовий до органічної інтеграції ІКТ у викладанні більшості навчальних предметів початкової школи. Застосування сучасних комп'ютерно-орієнтованих засобів навчання дозволяє кардинально змінити звичайні форми роботи вчителя, сприяє цікавому й повному розкриттю теми уроку, успішному і свідомому засвоєнню учнями навчального матеріалу. Засоби ІКТ уводять учнів у світ ігрових навчальних технологій, роблять учіння більш наочним і цікавим, і водночас забезпечують продуктивну та ефективну діяльність вчителя початкових класів.

Застосування IКТ дозволяє вчителю початкових класів економити час і максимально ефективно виконувати свої професійні обов'язки: складати конспекти уроків та виховних годин, готуватися до батьківських зборів, різноманітних виступів на педрадах, засіданнях методичного об'єднання, семінарах тощо, оформлювати документацію, в оперативному режимі відслідковувати результати навчальної діяльності учнів, налагоджувати спілкування з батьками своїх учнів, обмінюватися 3 колегами досвідом роботи, власними методичними надбаннями, обговорювати з ними актуальні питання навчання і виховання школярів тощо. 
Використання інформаційних технологій у навчальному процесі початкової школи та об'єднання їх із традиційними методами навчання ставить майбутніх фахівців перед необхідністю бути готовими до змін форм навчання, до удосконалення змісту навчальних дисциплін. На думку В. Барановської, сучасний учитель початкової школи повинен володіти основними прийомами роботи в Інтернеті, розуміти, як організовані служби глобальної мережі, якими ресурсами можна скористатися для поповнення методичних знань, як дізнатися через Інтернет про педагогічний досвід. Необхідними для вчителя є знання, навички та вміння щодо організації та виконання пошуку потрібних відомостей, що зберігаються у web-документах, здійснення за допомогою електронної пошти зв'язку 3 колегами. Для цього, як підкреслює дослідниця, учителеві необхідно оволодіти інформатичними компетентностями [1]. Отже, успішність майбутнього фахівця початкової освіти залежить від того, наскільки у нього сформовані вміння знаходити, класифікувати, представляти інформацію різними способами, активно й ефективно використовувати IКТ у професійній діяльності.

Невідповідність між слабкою підготовкою вчителя початкових класів у галузі використання комп'ютерних технологій у навчальному процесі і високою потребою в цих знаннях з боку школи можна розв'язати, на думку Л. Петухової, О. Співаковського, лише цілеспрямованим формуванням інформатичних компетентностей під час навчання у ВНЗ. При чому майбутні вчителі молодших класів повинні опанувати основи необхідних знань і накопити особистий досвід практичного використання комп'ютерних технологій, мати загальнокультурну і методичну підготовку щодо застосування у навчальному процесі [8, c. 8]. Отже, важливим завданням професійної підготовки майбутнього вчителя початкових класів є формування інформатичної компетентності як ключової складової професійної компетентності, комплексної характеристики системи знань, умінь і навичок набуття та трансформації інформації в професійно-педагогічній діяльності.

На думку М. Овчиннікової, майбутній учитель початкових класів повинен бути не лише грамотним користувачем персонального комп'ютера, який володіє навичками варіативного використання різного програмного забезпечення, а також повинен мати достатню базу знань, умінь, навичок і виражену мотивацію до постійного вдосконалення своїх знань, оскільки сучасне програмне забезпечення швидко модифікується [6]. Відтак, в інформаційному суспільстві цінуються вже не самі знання, а вміння їх самостійно здобувати та використовувати для розв'язання конкретних завдань. Тому важливим завданням педагогічного ВНЗ є не тільки надати студентам знання, сформувати вміння і розвинути навички, але й виробити у них постійну звичку самостійно поповнювати знання i забезпечити перенесення цієї звички у майбутню педагогічну й дослідницьку діяльність.

Високий рівень готовності вчителя початкової школи до використання інформаційних технологій, як слушно зауважує О. Суховірський, визначатиме надалі процеси розвитку інформаційного суспільства, інтенсифікацію інтеграції інформаційних технологій в життєдіяльність людини, а отже, і загальний рівень інформатизації суспільства [10, с. 12].

Отже, процес інформатизації освіти суттєво впливає на організацію професійної підготовки майбутніх учителів початкової школи. Зміни, що відбулися в системі освіти України, висувають нові вимоги до професійних якостей і рівня підготовки вчителів початкових класів. Підготовка вчителя початкової школи має бути спрямована не тільки на формування фундаментальних і професійних умінь й навичок, але й виховання особистості, яка вільно орієнтуватися в інформаційному просторі, володіє навичками варіативного використання програмного забезпечення, швидко знаходить, обробляє, зберігає, відтворює й 
продукує інформацію, ефективно використовує IКТ в навчально-виховному процесі початкової школи.

\section{Література}

1. Барановська В. М. Змістова характеристика стану та проблем формування інформатичних компетентностей майбутніх учителів початкових класів [Електроний ресурс]/ В. М. Барановська // Науковий вісник Донбасу. - 2012. - № 4. - Режим доступу: http://nbuv.gov.ua/j-pdf/nvd_2012_4_19.pdf 2. Бахмат Н. Конкурентоспроможність учителя початкової школи в умовах інформатизації освіти / Н. Бахмат // Проблеми підготовки сучасного вчителя. - 2014. - № 9 (1). - С. 257-263. 3. Дедюхина А. А. Педагогические условия формирования информационной компетентности будущих учителей начальных классов / А. А. Дедюхина // Теория и практика образования в современном мире: материалы междунар. науч. конф. (г. Санкт-Петербург, февраль 2012 г.). - Санкт-Петербург : Реноме, 2012. - С. 280-284. 4. Кушнір Н. О. Модель підготовки майбутніх учителів початкових класів до навчання основ інформаційно-комунікаційних технологій / Н. О. Кушнір // Інформаційні технології в освіті. - 2013. - № 17. - С. 147-153. 5. Михайлюк А. Ю. Про деякі напрямки інформатизації вищої освіти в умовах сьогодення / А. Ю. Михайлюк, М. В. Сніжко, Л. М. Бігун // Вища освіта України. - 2009. - Додаток 4, том I (13). - С. 457463. б. Овчинникова М. В. Использование компьютерных технологий в подготовке учителей начальных классов [Электронный ресурс] / M. В. Овчинникова // Форум конференций МГЛУ.- Режим доступу: http://conference.mdpu.org.ua/index.php 7. Олефиренко Н. В. Проблемы подготовки учителя начальной школы к проектированию дидактических электронных ресурсов [Электронный ресурс] / Н. В. Олефиренко // Образовательные технологии. - №1. - $\quad$ С. 577-589. - $\quad$ Режим доступа: http://ifets.ieee.org/russian/ depository/v17_i1/pdf/16.pdf. 8. Петухова Л. С. Актуальні питання формування інформатичних компетентностей майбутніх учителів початкових класів / Л. Є. Петухова, О. В. Співаковський // Комп’ютер у школі та сім’ї. - 2011. - № 1. - С. 7-11. 9. Співаковський О. В. Інформаційно-комунікаційні технології в початковій школі : [навч.метод. посіб.] / О. В. Співаковський, Л. Є. Петухова, В. В. Коткова. - Херсон: Айлант, 2012. 385 с. 10. Суховірський О. В. Підготовка майбутнього вчителя початкової школи до використання інформаційних технологій : автореф. дис. на здобуття наукового ступеня канд. пед. наук : спец. 13.00.04 «Теорія і методика професійної освіти»/ О. В. Суховірський; Інститут педагогіки АПН України. - Київ, 2005. - 20 с.

УДК 373.3.015.3

Олена Павлик

\section{ДИДАКТИЧНІ УМОВИ ФОРМУВАННЯ ТВОРЧОЇ ОСОБИСТОСТІ В КОНТЕКСТІ КОМПЕТЕНТНІСНОЇ ОСВІТИ}

Павлик О. А. Дидактичні умови формування творчої особистості в контексті компетентнісної освіти.

У статті розглядаються особливості процесу становлення творчої особистості, розкриваються педагогічні умови ефективності досліджуваного процесу. Висвітлено специфіку розвитку творчої особистості з огляду на завдання компетентнісного підходу в освіті.

Ключові слова: творча особистість, процес формування творчої особистості, 